\title{
Investigation on Microorganisms and their Degradation Efficiency in Paper and Pulp Mill Effluent
}

\author{
Radhakrishnan Saraswathi ${ }^{1^{*}}$, Manghatai Kesavan Saseetharan ${ }^{2}$ \\ ${ }^{1}$ Coimbatore Institute of Technology, Coimbatore, India \\ ${ }^{2}$ Government College of Technology, Coimbatore, India \\ E-mail: saraswathi70@rediffmail.com \\ Received April 16, 2010; revised June 11, 2010; accepted June 20, 2010
}

\begin{abstract}
Paper and pulp mill is a source of major pollution generating industry leaving huge amount of intensely colored effluent to the receiving end. Rapid increase of population and the increased demand for industrial establishments to meet human needs have created problems such as over exploitation of available resources, increased pollution taking place on land, air and water environment. The intention of this research paper is to identify predominant bacteria and fungi in paper and pulp mill effluent in addition to evaluate the degradation efficiency of individual isolates and combination of isolates. Treatment efficiency of individual isolates and combination of isolates are evaluated by shake flask method. Combination of Pseudomonas Alkaligenes, Bacillus subtilis along with Trichoderma reesei shows higher BOD, COD reduction of $99 \%$ and $85 \%$ respectively. As individual isolates Pseudomonas Alkaligenes show 92\% BOD reduction and 77\% COD reduction over other bacterial isolates and Trichoderma reesei removed 99\% BOD and 80\% COD respectively.
\end{abstract}

Keywords: Water Resource and Protection, Microorganisms, Degradation, Bacteria, Fungi, BOD, COD, Treatment Efficiency

\section{Introduction}

Paper and pulp mill is a large industrial enterprise that generates a significant amount of wastewater containing high concentration of lignin causing brown color and high Chemical Oxygen Demand. There has been considerable organic matter in pulp mill effluents on the environment. Some members of this family are known to be toxic, mutagenic, persist ant and bioaccumulating and are thought to cause numerous harmful disturbances in biological systems. There is no industry which does not add wastes into the environment. The introduction of contaminants through effluent and sludge to different environmental compartments can often overhelm the self cleansing capacity of recipient ecosystems and thus result in the accumulation of pollutants to problematic or even harmful levels. Prabu and Udayasoorian [1] reported that white rot fungus isolated from soil samples enriched by continuous pulp and paper mill effluent irrigation and identified as Phanerochaete chrysosporium was capable of $84 \%$ effluent decolourization along with $79 \%$ COD reduction.

Over several decades attempts have been made to re- move the dark color from the effluents. Of late industry follows either chemical oxidation/precipitation methods or biological methods for color removal. Chemical oxidation/precipitation methods are tedious, provide an additional environmental load. Biological methods are often preferred since it has many advantages like rapid biodegradation rates, low sludge yield and excellent process stability. Biological methods are of particular interest because they can also reduce chemical and biological demands (COD, BOD), which are also significant problem in pulp wastewater and so reduce holding times in aeration and sedimentation ponds prior to wastewater discharge into the environment [2-4].

A number of research studies have discovered that a group of extracellular isoenzymes called ligninases which are lignin peroxidase (LiP), manganese-dependent peroxidase $(\mathrm{MnP})$ and laccase produced by some microorganisms are capable of degrading lignin present in the paper and pulp mill effluent. de Oliveria et al. [5] evaluated the ability of these bacterias to remove color and COD from paper mill effluent. Bacillus pumilus CBMAI 0008 isolated from wood decomposition and Paenibacillus sp CBMAI 868 isolated from paper mill wastewater 
are able to produce alkaline enzymes under thermophilic conditions, including xylanases and manganese dependent peroxidase.

Some investigators have made an attempt to treat pulp and paper mill wastewater by the thermophilic temperature at which they are discharged to reduce energy cost for treatment. Reddy et al. [6] treated the pulp and paper mill effluent by using thermophilic microorganisms in batch systems. They compared the aerobic treatment of pulp and paper mill effluent at the temperatures of $40^{\circ} \mathrm{C}$, $50^{\circ} \mathrm{C}$ and $60^{\circ} \mathrm{C}$. Maximum removal efficiency of $55.2 \%$ was achieved at $40^{\circ} \mathrm{C}$. However once degradation is obtained the degradation rate decreases significantly as temperature increases. Ruiz-Ordaz et al. [7] investigated on phenol biodegradation using repeated batch culture of Candida tropicalis in a multistage bubble column. The phenol removal efficiency of $98.7 \%$ was achieved. Marihal et al. [8] utilized Rhizobacteria isolated from pentachlorophenol-tolerant crop species for biodegradation of pentachlorophenol. 90\% phenol reduction was achieved using these bacteria. Pentachlorophenol (PCP) is a polychlorinated aromatic compound that is widespread in industrial effluents and is considered to be a serious pollutant. PCP is also formed unintentionally in effluents of paper and pulp industries. A number of plant species were evaluated for their ability to tolerate different concentrations of Pentachlorophenol (PCP) in the soil. An important strategy for effluent treatment is the isolation and characterization of genetically significant microorganisms together with designing and optimization of process parameters to deal with specific environment pollutants. Nagarathnama et al. [9] successfully treated kraft mill effluent using Rhizopus oryzae. Rhizopus oryzae, a zygomycete, decolorize, dechlorinate and detoxify bleach plant effluent at lower cosubstrate concentration. With glucose at $\mathrm{g} / \mathrm{L}$, this fungus removed $92-$ $95 \%$ of the color, $50 \%$ of the chemical oxygen demand, $72 \%$ of the adsorbable organic halide and $37 \%$ of the extractable organic halide in 24 hour at temperatures of $25-45^{\circ} \mathrm{C}$ and a pH of 3-5. The aim of this research study is to begin with isolating the predominant fungi and bacteria present in pulp and paper mill effluent and evaluating the degradation efficiency of individual isolates and combination of isolates in laboratory scale.

\section{Materials and Methods}

\subsection{Effluent Source}

The effluent was obtained from SESHASAYEE PAPER MILL, Erode, Tamilnadu, a South Indian based Integrated Pulp and Paper Industry. The paper pulp effluent from the inlet, outlet of primary settling tank was used for investigation. The sample was collected using a sterile plastic container and transported to the RND Softech
Private Limited research laboratory situated in Coimbatore within 4 hours. The effluent was stored at $4^{\circ} \mathrm{C}$ until required.

\subsection{Methods}

All the testing was performed according to Standard Microbiological methods for the Examination of Water and Wastewater as described [10]. Shake flask method was used to evaluate the treatment efficiency of individual isolates and combination of isolates.

\subsection{Isolation and Identification of Predominant Microorganisms}

The sample was serially diluted using sterile pipettes from $10^{-1}$ to $10^{-8}$ dilution. Figure 1 shows bacterial and fungal strain capable of growing on Nutrient agar and PDA agar medium. Five different types of bacteria were predominant in the raw effluent; single type of fungi was found to be present. For enumeration of bacteria nutrient agar medium containing peptone $(5 \mathrm{~g} / \mathrm{L})$, yeast extract $(1.5 \mathrm{~g} / \mathrm{L})$, sodium chloride $(5 \mathrm{~g} / \mathrm{L})$, agar $(15 \mathrm{~g} / \mathrm{L})$ and for enumeration of fungi Potato dextrose agar containing potato $(200 \mathrm{gm})$, dextrose (20 gm, agar-15 gm, distilled water $(1000 \mathrm{~mL})$ at $\mathrm{pH} 5.6$ was used. To obtain pure culture the cultures were repeatedly streaked nutrient agar medium and incubated at $37^{\circ} \mathrm{C}$ for $24 \mathrm{hrs}$. The isolated bacteria were identified by colony morphology, gram staining, microscopic observation and confirmation test. The identified bacteria were Pseudomonas alkaligenes, Bacillus pumilus, Bacillus subtilis, Klebsielle sp, Proteus sp. The isolated fungal culture was identified as Trichoderma reesei using Lactophenol cotton blue staining method.

\section{Microbial Treatment of Effluent}

The raw effluent physiochemical parameters are given in Table 1. The raw effluent was treated using the isolated bacteria and fungi. The treatment efficiency was validated by calculating the percentage reduction of physiochemical parameters.

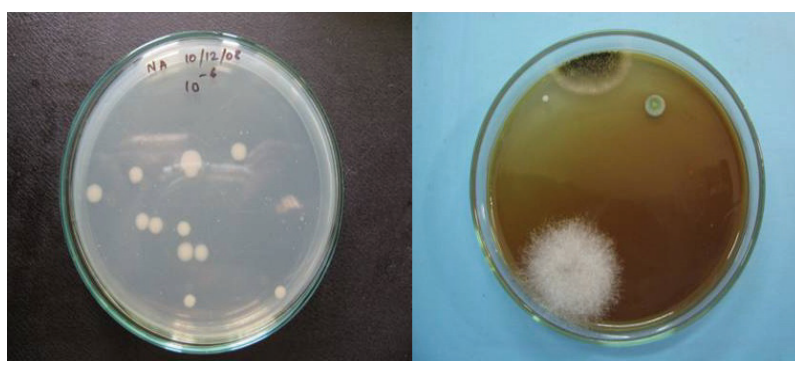

Figure 1. Bacterial and fungal strain growing on nutrient agar and PDA agar medium. 
Table 1. Physiochemical analysis of raw effluent (Inlet of Primary Clarifier).

\begin{tabular}{lc}
\hline \multicolumn{1}{c}{ Parameter } & Raw effluent \\
\hline $\mathrm{pH}$ & 7.5 \\
Color - Hazen & 117 \\
Total dissolved solids (mg/l) & 900 \\
Total suspended solids (mg/l) & 590 \\
Biochemical oxygen demand (mg/l) & 286 \\
Chemical oxygen demand (mg/l) & 1164 \\
Hardness (mg/l) & 56 \\
Chlorides (mg/l) & 40 \\
\hline
\end{tabular}

Table 2 gives the treatment efficiency of the five isolates for comparison and the isolates Klebsielle sp, Proteus sp, are excluded from further study as their percentage reduction of parameters are low compared to other three isolates.

\subsection{Different Combinatorial to Improve the Treatment Efficiency}

To improve the efficacy of the bacterial treatment, the three isolates found good are combined in possible ways as shown in Table 3 and the validation of the test is performed based on the same physio chemical parameters.

Combination 1 - Pseudomonas alkaligenes + Bacillus pumilus

Combination 2 - Pseudomonas alkaligenes + Bacillus subtilis.

Combination 3 - Bacillus pumilus + Bacillus subtilis.

Combination 4 - Pseudomonas alkaligenes + Bacillus
Table 3. Efficiency of treatment using different combinational.

\begin{tabular}{lcccc}
\hline $\begin{array}{c}\text { Parameters } \\
\text { studied }\end{array}$ & Comb.1 & Comb.2 & Comb.3 & Comb.4 \\
\hline $\mathrm{pH} *$ & 7.3 & 7.3 & 8 & 7.7 \\
TDS & 11 & 12 & 0 & 11 \\
TSS & 49 & 58 & 42 & 49 \\
BOD & 77 & 98 & 69 & 62 \\
COD & 59 & 77 & 66 & 69 \\
Hardness & 39 & 45 & 40 & 40 \\
Chlorides & 36 & 36 & 36 & 36 \\
Floc size & $0 *$ & $1.2 \mathrm{~mm}$ & $0 *$ & $1.1 \mathrm{~mm}$ \\
\hline
\end{tabular}

$\mathrm{pH}^{*}-$ Not in Percentage, $0 *-$ No floc formation

pumilus + Bacillus subtilis.

It was evident from Table 3 that combination 2 and combination 4 was found to be efficient compared to other combinations. Thus combination 2 and 4 are being used for further study.

Trichoderma reesei showed increased reduction of parameters and was found to be efficient in treatment of paper mill effluent. The efficient bacterial combination 2 (Pseudomonas alkaligenes + Bacillus subtilis) and combination 4 (Pseudomonas alkaligenes + Bacillus pumilus + Bacillus subtilis) shown in Table 3 and Trichoderma reesei shown in Table 4 were combined to enhance the treatment efficiency. It was evident from Table 5 that combination $2+$ Trichoderma reesei was competent compared with combination $4+$ Trichoderma reesei and the derived consortia was used for validation and standardization of process parameters.

Table 2. Treatment of effluent using the bacterial isolates.

\begin{tabular}{|c|c|c|c|c|c|}
\hline \multirow[b]{2}{*}{ Parameters studied } & \multicolumn{5}{|c|}{$\%$ reduction } \\
\hline & $\begin{array}{l}\text { Pseudomonas } \\
\text { alkaligenes }\end{array}$ & Bacillus pumilus & Bacillus subtilis. & Klebsielle sp & Proteus sp \\
\hline $\mathrm{pH} *$ & 7.3 & 7.5 & 7.5 & 7.1 & 7.8 \\
\hline TDS & 11 & 12 & 12 & 0 & 11 \\
\hline TSS & 58 & 60 & 59 & 35 & 20 \\
\hline BOD & 92 & 79 & 85 & 60 & 55 \\
\hline COD & 77 & 69 & 72 & 65 & 50 \\
\hline Hardness & 40 & 58 & 47 & 23 & 0 \\
\hline Chlorides & 36 & 32 & 29 & 11 & 11 \\
\hline Floc size & $1 \mathrm{~mm}$ & $2 \mathrm{~mm}$ & $1.3 \mathrm{~mm}$ & $0 *$ & $0 *$ \\
\hline
\end{tabular}

$\mathrm{pH} *$ - Not in Percentage, $0 *-$ No floc formation 
Table 4. Treatment of effluent using trichoderma reesei.

\begin{tabular}{lc}
\hline \multicolumn{1}{c}{ Parameter studied } & \% reduction \\
\hline $\mathrm{pH}^{*}$ & 6.2 \\
$\mathrm{TDS}$ & 22 \\
$\mathrm{TSS}$ & 45 \\
$\mathrm{BOD}$ & 99 \\
$\mathrm{COD}$ & 80 \\
Hardness & 56 \\
Chlorides & 39 \\
Floc size & $1.7 \mathrm{~mm}$ \\
\hline
\end{tabular}

$\mathrm{pH}^{*}-$ Not in Percentage

Table 5. Treatment of effluent using the bacterial isolates and fungus.

\begin{tabular}{lcc}
\hline $\begin{array}{c}\text { Parameters } \\
\text { studied }\end{array}$ & $\begin{array}{c}\text { \% reduction } \\
\text { Comb.2 + T.reesei }\end{array}$ & $\begin{array}{c}\text { \% reduction } \\
\text { Comb.4 + T.reesei }\end{array}$ \\
\hline $\mathrm{pH}^{*}$ & 7.2 & 6.9 \\
$\mathrm{TDS}$ & 22 & 12 \\
$\mathrm{TSS}$ & 59 & 52 \\
$\mathrm{BOD}$ & 99 & 82 \\
$\mathrm{COD}$ & 85 & 72 \\
Hardness & 56 & 40 \\
Chlorides & 40 & 36 \\
Floc size & $1.7 \mathrm{~mm}$ & $1.2 \mathrm{~mm}$ \\
\hline
\end{tabular}

$\mathrm{pH} *-$ Not in Percentage

\section{Results and Discussion}

It is implicitly known from Figure 2 that the percentage reduction of TSS, BOD, COD and Hardness seems higher but varying in all the combinations; Chlorides reduction was identical in all the four combinations, whereas there was no TDS reduction in combination 3. Effective floc formation was attained in combination 2 and combination 4 which enhance settling process. Figure 3 signifies that the treatment using Trichoderma reesei as individual isolate proved to be more efficient for the reduction of the parameters in paper and pulp mill effluent. Likewise Figure $\mathbf{4}$ be an evidence that the combination $2+$ Trichoderma reesei was superior in reducing paper and pulp mill effluent parameters. Figure 5 reveals the validation of treatment efficiency of combination 2 and Trichoderma reesei based on the research investigation.

\section{Concluding Remarks}

Pseusodomonas Alkaligenes, Bacillus pumilus, Bacillus subtilis proved to degrade paper and pulp mill waste effectively. The degradation rates achieved by these

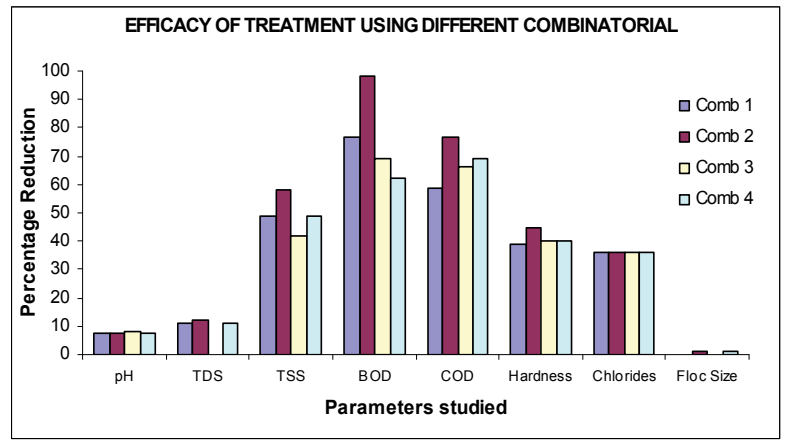

Figure 2. Treatment efficiency of different combinatorial.

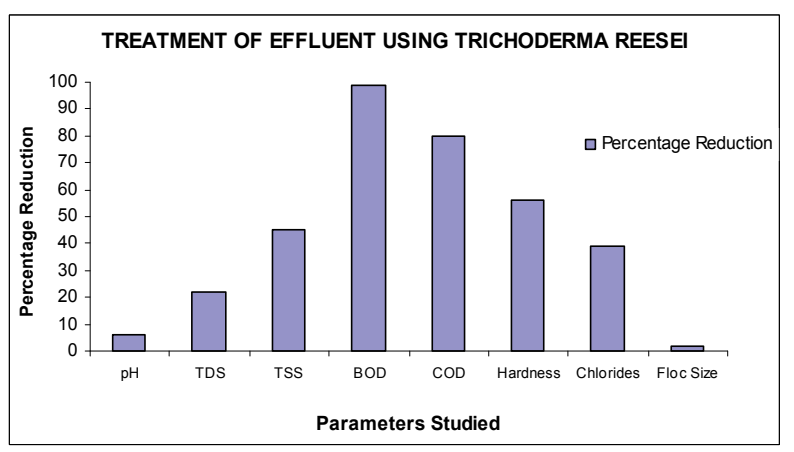

Figure 3. Effluent treatment using Trichoderma reesei.

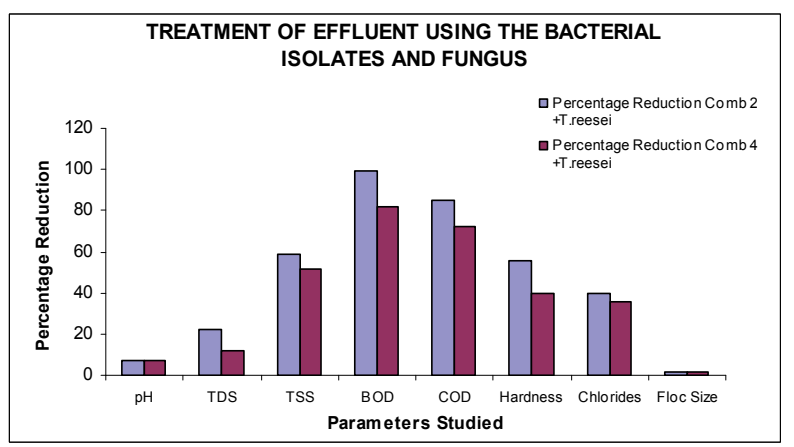

Figure 4. Effluent treatment using the bacterial isolates and fungus.

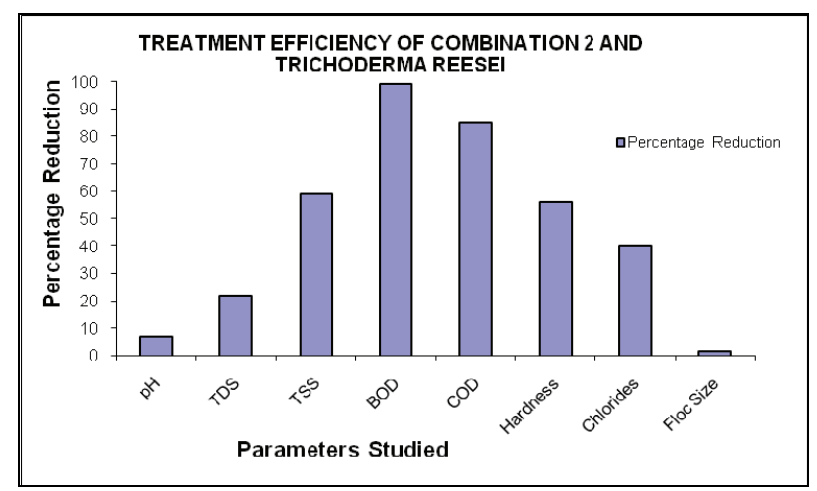

Figure 5. Treatment efficiency of combination 2 and Trichoderma reesei. 
isolates were $92 \%, 79 \%, 85 \%$ of BOD and $77 \%, 69 \%$, $72 \%$ COD respectively. Furthermore Pseusodomonas Alkaligenes kept higher degradation rate than other isolates. In combination of isolates, Combination 2 (Pseusodomonas Alkaligenes, Bacillus subtilis) showed $98 \%$ of BOD, 77\% COD removal and Combination 4 (Pseusodomonas Alkaligenes, Bacillus subtilis, Bacillus pumilus) showed $79 \%$ of BOD, $69 \%$ COD removal. Trichoderma reesei exhibited higher degradation activity on paper and pulp waste when used individually. $99 \%$ of BOD, $80 \%$ COD was achieved by this fungi. When bacteria and fungi were combined and used in treatment, 99\% BOD and 85\% COD reduction was achieved. The maximum COD reduction rate of $85 \%$ was observed when Bacillus subtilis was used individually and in the Combination of 2 along with Trichoderma reesei (Pseusodomonas Alkaligenes, Bacillus subtilis). Three isolates Pseusodomonas Alkaligenes, Bacillus pumilus, Trichoderma reesei both as individual isolates and in their combination proved to have more treatment efficiency rather than other isolates.

\section{References}

[1] P. C. Prabu and C. Udayasoorian, "Decolorization and Degradation of Phenolic Paper Mill Effluent by Native White Rot Fungus Phanerochaete Chyysosporium," Asian Journal of Plant Sciences, Vol. 4, No. 1, 2005, pp. 6063.

[2] S. Prasongsuk, P. Lotrakul, T. Imai and H. Punnapayak, "Decolourization of Pulp Mill Wastewater Using Thermotolerant White Rot Fungi," Science Asia, Vol. 35, 2009, pp. 37-41.

[3] A. P. Buzzini, M. A. Nolasco, A. M. Springer and E. C. Pires, "Evaluation of Aerobic and Anaerobic Treatment of Kraft Pulp Mill Effluent for Organochlorines Removal," Water Practice \& Technology, Vol. 1, No. 3, 2006.
[4] P. Singh and I. S. Thakur, "Removal of Color and Detoxification of Pulp Mill Effluent by Microorganisms in Two Step Bioreactor," Journal of Scientific \& Industrial Research, Vol. 63, No. 11, 2004, pp. 944-948.

[5] P. L. de Oliveira, C. T. D. Marta, A. N. Ponezi, L. R. Durrant, "Use of Bacillus Pumilus CBMAI 0008 and Paenibacillus SP.CBMAI 868 for Color Removal from Paper Mill Effluent," Brazilian Journal of Microbiology, Vol. 40, No. 2, 2009, pp. 354-357.

[6] P. Reddy, V. L. Pillay and A. K. S. Singh, "Degradation of Paper and Pulp Mill Effluent by Thermophilic Microorganisms Using Batch Systems," Water SA, Vol. 31, No. 4, 2005.

[7] N. Ruiz-ORDAZ, J. C. Ruiz-Lagunez, J. H. CastanonGonzalez, E. Hernandez-Manzano, E. Cristiani-Urbina and J. Galindez-Mayer, "Phenol Biodegradation Using a Repeated Batch Culture of Candida Tropicalis in a Multistage Bubble Column," Reviate Latinoamericana de Microbiologia, Vol. 43, 2001, pp. 19-25.

[8] K. Avita, Marihal, K. S. Jagadeesh and S. Sinha, "Biodegradation of PCP by the Rhizobacteria Isolated from Pentachlorophenol-Tolerant Crop Species," International Journal of Environmental Science and Engineering, Vol. 1, No. 4, 2009, pp. 189-193.

[9] R. Nagarathnama and P. Bajpai, "Decolorization and Detoxification of Extraction-Stage Effluent from Chlorine Bleaching of Kraft Pulp by Rhizopus Oryzae," $A p$ plied and Environmental Microbiology, Vol. 65, No. 3, 1999, pp. 1078-1082.

[10] APHA, AWWA, WPCF, "Standard Methods for the Examination of Water and Wastewater", 20th Edition, American Public Health Association, Washington, D.C., 1995.

[11] P. Sharma, L. Singh and N. Dilbaghi, "Biodegradation of Orange II Dye by Phanerochaete Chrysosporium in Simulated Wastewater," Journal of Scientific \& Industrial Research, Vol. 68, 2009, pp. 157-161. 